\title{
Konflik Kepemimpinan Jamaah Tabligh Di Kota Padang, Sumatera Barat
}

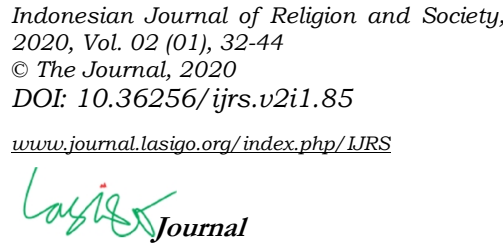

Article History

Received: March, 17th 2020

Revised: April, $22^{\text {th }} 2020$

Accepted: May, 17 th 2020

\section{Muhammad Aqil}

Program Studi Agama dan Resolusi Konflik, Fakultas Ushuluddin, UIN Sunan Kalijaga, Yogyakarta. muhammadaqi1312@gmail.com

\begin{abstract}
In da'wah, the Jama'at Tabligh offers a more friendly and polite format of Islam, because in their da'wah they have the principle of ikram al-muslim or glorifying fellow Muslims. In addition they are also known as organizations that avoid the problem of khilafiyah. However, the stigma is violated because they internal conflicts. This study aims to examine the internal conflicts of Tablighi Jamaat. This study focuses on looking the background and the dynamic of conflict that occur in the internal of Jamaah Tabligh. This study uses qualitative methods and conflict triangle theory developed by Johan Galtung. The findings of study indicate the conflict is caused by the problem of leadership or determination of amir. This leadership conflict made the Tabligh Jamaah split into two groups namely the Syuro Alami group and Nizamuddin. The Natural Syuro group made the Muhammadan Mosque in Pondok, Padang as headquarters, while the Nizamuddin group made the Madinatul Munawarah Mosque in the city of Padang as headquarters. At present what happens between the two groups is throwing accusations at each other and berating each other. The conflict caused mutual accusations and verbal abuse between the two groups.
\end{abstract}

Keywords: Jama'at Tabligh, Conflict, Syuro Alami, Nizamuddin.

\begin{abstract}
ABSTRAK
Dalam berdakwah, Jamaah Tabligh dikenal menawarkan format Islam yang lebih ramah dan santun karena mempunyai prinsip ikram al muslim atau memuliakan sesama muslim. Selain itu, mereka juga dikenal sebagai organisasi yang menghindari khilafiyah. Namun saat ini stigma tersebut dilanggar dan mereka terlibat konflik internal. Penelitian ini bertujuan mndiskusikan konflik Internal Jamaah Tabligh. Penelitian ini fokus melihat latar belakang dan dinamika konflik yang terjadi di internal Jamaah Tabligh. Penelitian ini menggunakan metode kualitatif dan teori segitiga konflik yang dikembangkan oleh Johan Galtung. Temuan penelitian menunjukkan bahwa akar penyebab konflik adalah masalah kepemimpinan atau penentuan amir. Konflik kepemimpinan ini menjadikan Jamaah Tabligh terbelah menjadi dua kelompok, yakni kelompok Syuro Alami dan Nizamuddin. Kelompok Syuro Alami menjadikan Masjid Muhammadan di Pondok, Kota Padang sebagai markas,, sedangkan kelompok Nizamuddin menjadikan Masjid Madinatul Munawarah di Berok, kota Padang sebagai markas. Konflik menyebabkan terjadinya saling lempar tuduhan dan caci maki antar kedua kelompok.
\end{abstract}

Kata Kunci: Jamaah Tabligh, Konflik, Syuro Alami, Nizamuddin.

Corresponding Author

Name : Muhammad Aqil

Email : muhammadaqi1312@gmail.com 
Indonesian Journal of Religion and Society 2020, 02 (01) | 33

\section{Pendahuluan}

Jamaah Tabligh merupakan salah satu kelompok keagamaan yang berorientasi menjalankan misi dakwahnya. Kelompok ini memiliki keunikan dan kekhasan tersendiri dibandingkan dengan aliran-aliran lain yang lebih dulu muncul di Indonesia. Keunikan dan kekhasan Jamaah Tabligh terlihat pada gerakan dakwahnya yang selalu keluar meninggalkan rumah dan keluarganya dalam kurun waktu tertentu menuju satu perkampungan atau daerah secara berpindah-pindah dari satu kampung ke kampung yang lain, dari satu tempat ke tempat yang lain, dari satu masjid ke masjid yang lain. Kegiatan mereka disebut dengan khuruj atau keluar berjauhan dari rumah (Saepuloh, 2014). Kelompok ini menggunakan metode dakwah dengan simpatik dan akhlak yang baik dengan semangat ukhuwah dan tidak sektarian serta mengindari masalah khilafiyah (Hasanah, 2014). Tujuan dakwah mereka adalah untuk menegakkan kembali amalan-amalan agama yang sesuai dengan Al-Quran dan sunnah. Namun, akhir-akhir ini Kelompok yang mengedepankan dakwah untuk menegakkan serta mengajak kepada yang ma'ruf dan menghindari masalah khilafiyah, justru bertentangan dengan prinsip yang mereka pegang. Di internal mereka justru saling caci dan mengakibatkan terjadinya konflik dan perpecahan.

Konflik yang terjadi pada Jamaah Tabligh berawal dari markas pusat internasional di Nizamuddin India. Masalahnya adalah perebutan pemimpin. Saat ini terdapat dua kubu Jamaah Tabligh, pertama adalah kubu yang setia kepada Maulana Saad sebagai amir dunia atau ketua, dan kbubu kedua adalah kelompok yang tidak setuju pada Maulana Saad dan kemudian membentuk majelis Syuro dunia. Sejak saat itulah secara internasional jamaah tabligh terpecah menjadi dua kelompok, yaitu kelompok keamiran, yaitu Keamiran Nizamuddin yang setia kepada Maulana Saad dan Majelis Syuro dunia yang menentang keamiran atau kepemimpinan Maulana Saad. Konflik ini meluas hingga ke seluruh cabang Jamaah Tabligh yang ada di seluruh dunia, tak terkecuali cabang di Indonesia, termasuk kota Padang (Wawancara dengan YM, 2019).

Jamaah Tabligh di Padang memusatkan aktivitas dakwahnya di Masjid Muhammadan yang terletak di Pasa Gadang, kawasan Pondok. Masjid ini sekaligus adalah markas provinsi Jamaah Tabligh di Sumatera Barat. Kegiatan Jamaah Tabligh di Masjid Muhammadan dilaksanakan setiap senin dan kamis malam. Kegiatan senin malam adalah musyawarah, dan kegiatan kamis malam merupakan malam markas. Kegiatan yang dilaksanakan pada malam markas adalah ceramah agama yang disampaikan oleh salah seorang jamaah yang telah ditunjuk pada malam musyawarah. Inti dari ceramah yang disampaikan adalah untuk menumbuhkan rasa risau terhadap keadaan umat dan mau berjuang untuk memperbaiki keadaan umat yang sudah banyak menyimpang dari ajaran agama.

Biasanya, pada setiapk senin malam dan kamis malam kegiatan rutin ini dihadiri oleh ribuan jamaah yang datang dari berbagai daerah di kota Padang maupun di luar kota Padang. Namun, setelah terjadinya konflik yang mengakibatkan jamaah tabligh terpecah menjadi dua kelompok, malam musyawarah dan malam markas yang biasanya dihadiri oleh ratusan bahkan ribuan jamaah di masjid Muhammadan mulai berkurang. Hal ini disebabkan sebagian jamaah yang setuju terhadap kepemimpinan Maulana Saad sebagai amir dunia memilih keluar dari Masjid Muhammadan dan membangun Masjid baru sebagai markas di Berok, Kota Padang dengan nama masjid Madinah Al-Munawarah. Masjid ini dijadikan sebagai markas dari kelompok jamaah tabligh yang setia terhadap kepemimpinan Maulana Saad. Sejak saat itu, di tahun 2017 jamaah tabligh di kota Padang terpecah menjadi dua kelompok sampai penelitian ini dilakukan.

Jamaah Tabligh selama ini dalam menjalankan misi dakwahnya lebih menonjolkan format Islam yang lebih ramah, santun dan mengedepankan pendekatan akhlak yang baik kepada masyarakat. Mereka hanya fokus menegakkan yang ma'ruf dan mengerjakan segala bentuk amalan-amalan yang sesuai dengan tuntutan Al-Quran dan sunnah untuk bekal persiapan di akhirat nanti. Hal tersebut memang tidak bisa dipungkiri sebab salah satu doktrin terpenting dari ajaran dakwah Jamaah Tabligh adalah prinsip ikram al-Muslim (menghormati atau memuliakan setiap individu muslim) yang merupakan salah satu prinsip yang mengantarkan gerakan dakwah ini diterima oleh masyarakat muslim secara luas hingga berkembang sangat pesat. Prinsip ini benar-benar membuka peluang yang besar bagi terciptanya persatuan dan kesatuan kaum muslimin atas landasan ikwah Islamiyah (persaudaraan atas nama Islam) di mana prinsip ini melarang seorang mukmin 
mempermasalahkan aliran pemahaman, pilihan politik, kedudukan, serta latar belakang status sosial individu muslim lainnya (Yusuf, 2015).

Jamaah Tabligh melihat bahwa ikram al-muslim adalah ajaran agama yang harus ditanam ke tengah-tengah masyarakat luas. Seseorang yang sudah ber-islam, maka orang tersebut adalah saudara dan harus diperlakukan secara terhormat. Sikap terhadap sesama muslim harus lebih mendahulukan perasaan dan pikiran yang positif daripada menaruh perasaan curiga dan berpikir secara negatif. Maka hal-hal yang mengarah kepada terbukanya emosi, ketersinggungan, dan curiga harus dihindari. Salah satu caranya adalah dengan tidak mempermasalahkan latar belakang maupun status sosial muslim di tengahtengah masyarakat. Selama ia seorang muslim, maka ia harus diperlakukan secara mulia. Bagi Jamaah Tabligh, seluruh kaum muslimin di dunia ini adalah saudara yang harus dimuliakan, tidak peduli apapun pilihan politik, status sosial, jabatan, aliran pemahaman keagamaan, amaliyah, dan lain sebagainya. Ikram al-muslim adalah salah satu sifat paling menonjol dari para al-salaf al salih, yaitu para sahabat nabi dan orang-orang yang mengikuti jalan hidup mereka. Sifat penting ini terangkum dalam enam sifat sahabat, yaitu sifat al sittah (enam sifat) yang menjadi prinsip gerakan dakwah Jamaah Tabligh (Musyawarah ahli syuro dan para jumidar, 2018; Yusuf, 2015).

Ada berbagai studi yang dilakukan terkait Jamaah Tabligh namun tentunya dengan konsep dan dimensi yang berbeda-beda diantaranya studi yang dilakukan oleh Didi Junaedi (2013), yang menyoroti tentang penafsiran Jamaah Tabligh terhadap ayat Al-Quran dan Hadis, dalam studi ini ditemukan bahwa Jamaah Tabligh dalam memahami Al-Quran dan Hadis lebih melihat pada aspek literal tekstual daripada makna substantif kontekstual, dengan kata lain subjektivitas penafsiran mereka lebih terlihat daripada objektivitasnya. Kemudian studi yang dilakukan oleh Tholhah (2015) menyoroti peranan Jamaah Tabligh di Asia Selatan terhadap perkembangan Jamaah Tabligh yang ada di Yogyakarta. Studi ini menunjukkan bahwa Jamaah Tabligh di Yogyakarta mendapat instruksi dari para masyaikh untuk mengembangkan ideologi Jamaah Tabligh dengan menggunakan pendekatan sosial kultur budaya yang ada di Yogyakarta. Kemudian studi yang dilakukan oleh Umdatul Hasanah (2014) tentang reaksi masyarakat terhadap keberadaan kelompok Jamaah Tabligh. Penelitian ini menunjukkan bahwa keberadaan Jamaah Tabligh mendapat respon yang positif dan negatif di tengah masyarakat. Dengan pesatnya jumlah anggota Jamaah Tabligh yang bertambah tentu menjadi bukti bahwa keberadaannya direspon positif oleh masyarakat. Kemudian dengan masih adanya kasus-kasus pengusiran juru dakwah Jamaah Tabligh juga menjadi bukti masih adanya respon negatif dari masyarakat.

Pada dasarnya Ketiga studi tersebut membahas tentang Jamaah Tabligh, hanyasaja seluruh studi tersebut kebanyakan berfokus membahas respon masyarakat terhadap gerakan dakwah Jamaah Tabligh dan prinsip yang dipegang oleh juru dakwah Jamaah Tabligh dalam menjalankan gerakannya. Penelitian ini tentunya berbeda dengan ketiga penelitian di atas, sebab penelitian ini akan lebih berfokus pada konflik yang terjadi dalam internal Jamaah Tabligh. Dimensi ini belum tersentuh oleh ketiga studi sebelumnya. Ibnu Burdah, seorang pemerhati Timur Tengah dan dunia Islam dari UIN Sunan Kalijaga menjelaskan bahwa Jamaah Tabligh merupakan organisasi Islam transnasional yang saat ini paling pesat perkembangannya. Beliau menegaskan pesatnya perkembangan Jamaah Tabligh baik di dunia maupun di Indonesia dikarenakan adanya daya tarik yang tidak dimiliki oleh organisasi keagamaan lainnya. Daya tarik itu terletak untuk tidak berpolitik dan menghindari masalah khilafiyah, baik itu fiqih, mazhab dan tarekat. Sikap yang konsisten ini menjadi poin penting bagi kuatnya penyebaran Jamaah Tabligh baik di Indonesia maupun di dunia. Namun, prinsip ini seakan-akan hilang dan dilupakan dengan adanya konflik. Mereka yang sebelumnya memegang prinsip untuk tidak berpolitik justru saat ini terlibat dalam konflik politik, yaitu konflik kepemimpinan atau kekuasaan. Oleh karena itu penelitian ini menjadi penting dan menarik untuk dikaji guna mengetahui realitas baru yang saat ini terjadi di internal Jamaah Tabligh. Maka dari itu penelitian ini fokus pada dinamika konflik yang terjadi pada di internal Jamaah Tabligh dan perbedaanperbedaan mendasar pada Jamaah Tabligh setelah terjadi konflik.

\section{Kerangka Teori}

Untuk memahami konflik dalam jamaah tabligh penelitian ini menggunakan teori segitiga konflik dari Johan Galtung. Galtung merumuskan konflik dalam satu segitiga, yang disebut $A B C$ Triangle. $\mathrm{ABC}$ dalam segitiga konflik Galtung merupakan urutan terbentuknya konflik yang terdiri atas Attitudes (A), Behaviour (B) dan Contradiction (C). Attitude mencakup 
asumsi, kognisi dan emosi yang dimiliki satu pihak terhadap pihak lain. Attitude dalam konflik juga berarti adanya penolakan terhadap superioritas pihak lain. Asumsi yang dibangun bisa bersifat positif dan negatif, akan tetapi dalam konflik kekerasan, kecenderungan yang muncul adalah menciptakan asumsi negatif terhadap pihak musuh, sebagai akibat dari kemarahan dan ketidakamanan. Behaviour adalah mental, ekspresi verbal atau fisik yang timbul dalam konflik. Tindak kekerasan, penghinaan, sikap tidak hormat, kejahatan seksual dan pelanggaran hak asasi manusia adalah bentuk-bentuk behaviour dalam konflik. Sehingga behaviour adalah bentuk aksi nyata yang ada dalam konflik. Sedangkan contradiction merupakan bagian penting dalam konflik yang menunjukkan adanya perbedaan ataupun kontradiksi tujuan antar pihak yang berkonflik. Contradiction menjadi bagian yang penting karena hal ini menyebabkan tindak kekerasan dan perilaku (Gati, 2014).

Galtung berpendapat bahwa tiga komponen harus muncul bersama-sama dalam sebuah konflik total (Miall, 2002). Ketiga komponen tersebut merupakan urutan terbentuknya konflik yang meliputi kontradiksi, sikap dan perilaku (Galtung, 2003). Adapun komponen contradiction akan digunakan untuk mengetahui bagaimana kontradiksi yang terjadi antar jamaah karena perbedaan persepsi atau perbedaan tujuan dari kelompok yang bertikai. Persepsi pihak-pihak yang bertikai cenderung mengembangkan stereotip yang merendahkan pihak masing-masing. Setelah adanya kontradiksi akan membentuk komponen kedua, yakni attitude (sikap). Komponen yang kedua ini akan digunakan untuk melihat sikap para anggota Jamaah Tabligh, apakah sikap yang diperlihatkan cenderung merendahkan dan berpandangan selalu negatif antar kelompok yang bertikai atau sikapsikap yang memicu lahirnya konflik seperti yang disebutkan Galtung yakni sikap kemarahan, kebencian dan kepahitan. Setelah sikap ini terbentuk fase selanjutnya akan melahirkan sebuah behavior (perilaku) konflik kekerasan, yang merupakan komponen ketiga dari urutan terbentuknya konflik. Perilaku tersebut bisa dalam bentuk ancaman, pemaksaan dan serangan yang merusak. Komponen yang ketiga ini akan digunakan untuk melihat perilaku para anggota Jamaah Tabligh, baik perilaku yang menunjukkan penyerangan yang tentu akan melahirkan konfrontasi fisik dan perilaku-perilaku negatif lain dalam menyikapi konflik internal yang terjadi.

Teori segitiga ini juga akan digunakan untuk menganalisis, apakah ketiga komponen di atas yang merupakan urutan terbentuknya konflik dapat membawa kepada konflik yang lebih luas atau melebar, sebab Galtung melihat konflik sebagai proses dinamis dimana struktur sikap dan perilaku secara konstan berubah dan mempengaruhi satu sama lain. Ketika konflik muncul, konflik menjadi formasi konflik ketika kepentingan pihak-pihak yang bertikai masuk ke dalam konflik atau hubungan dimana mereka berada menjadi penindas. Kemudian pihak-pihak yang bertikai mengorgansasikan diri di sekitar struktur ini untuk mengejar kepentingan mereka. Mereka mengembangka sikap yang membahayakan dan perilaku yang bersifat konflik. Dengan begitu formasi konflik mulai tumbuh dan berkembang sebagaimana yang biasa terjadi, konflik dapat melebar, menarik pihak-pihak lain, semakin mendalam dan menyebar, menimbulkan konflik-konflik sekunder pada pihak-pihak utama atau di antara pihak-pihak yang berada di luar sekarang terseret masuk (Miall, 2002).

\section{Metode Penelitian}

Penelitian ini merupakan penelitian lapangan dengan pendekatan kualitatif. Penelitian dilaksanakan di bulan Juli hingga Agustus 2019, Lokasi penelitian ini adalah di Masjid Muhammadan, Pondok, Kota Padang sebagai markas kelompok Syuro Alami dan Masjid Madinatul Munawarah, Berok, Kota Padang sebagai markas dari kelompok keamiran (Nizamuddin). Penelitian ini berupaya mendeskripsikan akar masalah terjadinya konflik dan bentuk konflik Jamaah Tabligh di kota Padang. Ada tiga bentuk teknik pengumpulan data lapangan yang telah dilakukan, yakni observasi, wawancara dan dokumentasi. Metode Observasi yang digunakan dalam penelitian ini adalah partisipan observer, yaitu peneliti terlibat secara langsung, mengamati dengan seksama terhadap objek penelitian. Dalam konteks ini peneliti mengamati langsung kedua kelompok yang terpecah pada Jamaah Tabligh di kota Padang, yakni di Masjid Muhammadan sebagai pusat dakwah dari kelompok Syuro Alami dan Masjid Madinatul Munawarah sebagai pusat dakwah dari kelompok keamiran atau Nizamuddin di kota Padang. Observasi yang dilakukan terfokus pada aktivitas dakwah dan perilaku para anggota Jamaah Tabligh. Untuk wawancara, informan dipilih dengan menggunakan teknik snowball sampling, yaitu mencari informasi 
kunci, kemudian dilanjutkan kepada informan-informan lainnya sampai kepada tingkat kejenuhan. Informan dalam penelitian ini diantaranya adalah para anggota Jamaah Tabligh serta para tokoh dalam jamaah tabligh. Dalam penelitian ini teknik Wawancara yang digunakan adalah wawancara tidak terstruktur (unstructured interview), dan dilakukan dengan face to face (Sugiyono, 2019). Wawancara tidak terstruktur ini tidak dilakukan dengan struktur yang ketat, namun peneliti mengajukan pertanyaan yang lebih terarah pada tujuan utama penelitian ini. Selanjutnya metode dokumentasi yaitu pencarian data mengenai penelitian yang terdapat di buku-buku dan jurnal-jurnal yang terkait dengan tema penelitian.

Adapun Teknik analisis data dalam studi ini dilakukan dengan menggunakan analisis deskriptif kualitatif, yaitu mengolah dan menyajikan data dengan melaporkan apa yang telah diperoleh selama penelitian dengan cermat dan teliti serta memberikan interpretasi. Adapun analisis data dilakukan dengan mengumpulkan data. Setelah itu peneliti melakukan seleksi, sehingga bisa ditentukan data mana yang bisa masuk dalam kerangka konseptual tulisan dan mana yang harus disisihkan. Selanjutnya, data tersebut difokuskan sehingga hasilnya adalah sebuah abstraksi yang terarah dan mengena dengan kajian yang dilakukan.Penelitian ini tidak disajikan sekedar deskriptif saja, akan tetapi disertai analisis yang mana data diinterpretasi, sehingga data yang telah diorganisasikan tadi memiliki makna yang mudah dipahami. Langkah-langkah di atas mengacu pada Miles dan Huberman yang menyatakan bahwa analisis data mencakup tiga sub proses, pertama: editing dan reduksi yang terdiri dari kegiatan memperbaiki, menggolongkan data, menguraikan data, serta membuang yang tidak perlu dan mengorganisir data, kedua: penyajian dan analisis data secara naratif, dan ketiga interpretasi dan penarikan kesimpulan (Miles \& Huberman, 1992).

\section{Sejarah Masuk dan Perkembangan Jamaah Tabligh di Kota Padang}

Jamaah Tabligh sampai di Kota Padang melalui rombongan yang dikirim dari kota Medan, Sumatera Utara. Rombongan ini sampai ke Padang terutama karena dibujuk oleh orang Minangkabau di perantauan yang ikut dalam pengajian Jemaah Tabligh dan ingin agar metode dakwah ini juga dikenal di Minangkabau. Pada tahun 1985, satu rombongan Jamaah yang berasal dari Kota Medan, Sumatera Utara datang ke masjid Muhammadan yang terletak di Jalan Pasar Batipuh, Kampung Keling Padang, dengan jumlah anggota sebanyak 16 orang. Rombongan dipimpin oleh Irwan Parindra, seorang mahasiswa USU yang didampingi oleh Hasan Basri, salah seorang Amir Syaf (penanggung jawab) Jamaah Tabligh di Kota Medan. Kedatangan rombongan ini menjadi foundament perkembangan Jamaah Tabligh di Kota Padang dan Sumatera Barat untuk masa selanjutnya.

Rombongan yang datang dari Kota Medan ini, melakukan I'tikaf di Masjid Muhammadan selama tiga hari. Selama i'tikaf, jamaah Masjid Muhammadan yang sebagian besar adalah warga keturunan India mengenal mereka lebih dalam. Mereka menekankan bahwa mereka yang datang dan jamaah tempatan diikat oleh kalimat Laa ilaha ilallah, Muhammadur Rasulullah (Witrianto, 2015).Di antara jamaah Masjid Muhammadan ada yang merasa tertarik dengan kegiatan yang dilakukan rombongan ini, karena sebelumnya mereka pun juga memiliki kerisauan yang sama dengan yang dimiliki oleh rombongan ini mengenai kondisi umat Islam. Pada saat itu, Masjid Muhammadan ditetapkan sebagai tempat bermusyawarah (belum berbentuk markaz) pada perkembangan selanjutnya, malam musyawarah ditetapkan pada hari Senin malam, sedangkan hari Kamis malam ditetapkan sebagai Malam Markaz.

Masjid Muhammadan sendiri, sebagai markaz Sumatera Barat juga mengeluarkan rombongan secara rutin, yang terdiri dari jamaah 40 hari, jamaah 4 bulan, jamaah 4 bulan jalan kaki, dan jamaah masturah (perempuan) yang harus didampingi oleh muhrimnya. Pada tahap awal, Masjid Muhammadan juga mengeluarkan rombongan tiga hari setiap minggunya, tetapi kemudian rombongan tiga hari ditangani oleh marhalah (masjid tempat anggota jamaah tinggal) atau halaqah (gabungan dari marhalah) yang berada pada satu wilayah yang sama). Rombongan tiga hari akan keluar dari halaqah jika marhalah tidak sanggup mengeluarkan satu rombongan jamaah tiga hari setiap bulannya.

Pengiriman jamaah kuruj, atau biasa disebut keluar dari Masjid Muhammadan pertama kali dilakukan pada tahun 1988, tiga tahun setelah kedatangan rombongan dari Medan. Pengalaman pertama ini memberikan spirit dan kesan yang kuat bagi anggotanya sehingga kegiatan khuruj tetap berlanjut setiap bulan dan mulai menyebar ke beberapa masjid di Kota Padang. Selama dua dasawarsa terakhir, keberadaan Jamaah Tabligh telah mewarnai 
sejarah gerakan Islam di Kota Padang. Pusat kegiatan Jamaah tabligh untuk wilayah Kota Padang dan Sumatera Barat adalah Masjid Muhammadan (Witrianto, 2015).

\section{Konflik Jamaah Tabligh 5.1. Latar Belakang Konflik}

Jamaah Tabligh merupakan gerakan keagamaan transnasional yang pada mulanya lahir dan berkembang di India. Gerakan ini lahir pada tahun 1926 di Mewat India, dengan pendirinya Syaikh Muhammad Ilyas bin Muhammad Ismail al Kandahlawi al-Deobandi al-Jisyti (18851944). Setelah Maulana Muhammad Ilyas meninggal, kepemimpinan diteruskan oleh puteranya, Maulana Muhammad Yusuf al-Kandahlawi (1917-1965). Pada masa inilah Jamaah Tabligh mengalami perkembangan yang pesat, kurang dari dua dekade selama masa kepemimpinan Maulana Yusuf, gerakan ini berhasil mengembangkan aktivitas dakwahnya hingga ke Amerika dan Eropa (Kamaruddin, 2010). Setelah Maulana Yusuf mangkat, estafet kepemimpinan dilanjutkan oleh Maulana Inamul Hasan. Selama masa kepemimpinan beliau inilah bibit-bibit perpecahan mulai muncul ketika Maulana Inamul Hasan membentuk Syuro yang beranggotakan 10 Orang karena beliau telah sakit-sakitan. 10 orang syuro ditunjuk untuk dengan menggantikan tugasnya saat sakit.

Semua anggota Syuro berasal dari India sebanyak 5 orang, yaitu Maulana Izhar, Maulana Zubair, Maulana Saad, Maulana Umar Phalampuri, dan Meyaji Mehrob. Sebanyak 4 orang berasal dari Pakistan, yaitu Syeikh Abdul Wahab, Mufti Zainal Abidin, Maulana Said Ahmad Khan, Bhai Afdol, dan 1 orang dari Bangladesh, yaitu Ir Abdul Muqit. Setelah Syekh Inamul Hasan meninggal, 10 orang syuro yang telah ditunjuk sebelumnya bermusyawarah untuk menentukan siapa amir selanjutnya. Namun musyawarah tersebut menemui jalan buntu karena ke 10 anggota syuro gagal menentukan kesepakatan siapa amir selanjutnya. Dan musyawarah tersebut pecah menjadi $3 \mathrm{kubu}$, Pertama, Orang-orang Mewat ingin Maulana Saad menjadi Amir, kedua, orang-orang Sahranpur ingin Maulana Izhar jadi Amir, ketiga. orang-orang Delhi ingin Maulana Zubair jadi amir. Dalam musyawarah Maulana Saad mengatakan "kalau kalian tunjuk saya jadi amir maka pengikut setia Maulana Zubair akan pergi, kalau kalian angkat Maulana Zubair orang-orang Mewat yang mengikuti saya akan pergi". Maulana Saad pun memberi solusi dengan tidak ada ada amir, 3 orang dari 3 kubu menjadi faisalat yaitu Maulana Saad, Maulana Izhar dan Maulana Zubair. Akhirnya karena kebuntuan dalam musyawarah tersebut, atas usulan dari Maulana Saad kepemimpinan diputuskan dengan berlakunya sistem kolegial dengan tiga faisalat, yaitu Maulana Saad, Maulana Izhar dan Maulana Zubair (Syeirazi, 2019).

Setelah Maulana Izhar dan Maulana Zubair meninggal, maka secara otomatis Maulana Saad menjadi faisalat tunggal atau Amir dakwah. Dari tahap inilah masalah mulai muncul. Dilansir dari situs NU online yang ditulis oleh M. Kholid Syeirazi, bahwa secara sepihak Maulana Saad dianggap mengangkat dirinya sebagai Amir pada Ijtimak di Bophal November 2015. Hal ini seperti yang diungkapkan oleh YM dan HR yang merupakan anggota Syuro Alami kota Padang. "Maulana Saad itu mengaku sebagai amir, padahal pasca tahun 1993 itu tidak ada lagi sistem
keamiran yang ada adalah sistem syuro musyawarah" (wawancara dengan YM, 11 Juli 2019).

"Maulana Saad itu merasa menjadi amir dan kemirannya itu tanpa adanya sistem musyawarah, kemudian Maulana Saad memisahkan diri dari syuro dan merasa menjadi amir dunia" (wawancara dengan HR, 2 Agustus 2019).

Namun, hal ini dibantah oleh para pendukung Maulana Saad dengan menyebutkan bahwa setelah Maulana Zubair meninggal dunia, maka dari berbagai pihak meminta dan mendesak agar Maulana Saad bersedia dibaiat. Akhirnya, Maulana Saad menerima dibaiat tanpa musyawarah lagi pada tahun 2014. Pendukung dari Maulana Saad menjelaskan bahwa permintaan untuk menjadikan Maulana Saad sebagai amir bukan datang dari Maulana Saad sendiri, melainkan dari kecintaan Jamaah kepada Maulana Saad karena beliau sudah menjadi faisalah tunggal setelah wafatnya Maulana Zubair.

Kelompok Nizamuddin membantah statement kelompok Syuro Alami tersebut dengan menyatakan bahwa tidak ada amir setelah Maulana Inamul Hasan meninggal. Sebagaimana wawancara yang penulis lakukan dengan R salah seorang anggota kelompok Nizamuddin.

"tidak ada ucapan dari Maulana Inamul Hasan, tidak boleh ada amir setelah beliau. Buktinya 10 orang syuro yang ditunjuk Maulana Inamul Hasan bermusyawarah untuk mengangkat amir. Setelah wafatnya Maulana Inamul Hasan.Alhamdulillah, masih banyak saksi hidup yang sampai 
sekarang masih berada di markas Nizamuddin (markas dunia), maka yang menjadi amir di Nizamuddin India adalah amir bagi jamaah dakwah seluruh dunia)" (wawancara dengan R, 21 Agustus 2019).

Sejak peristiwa itulah Jamaah Tabligh mulai terbelah klaim secara sepihak ini dianggap cacat oleh mereka yang protes dipimpin oleh Abdul Wahab yang merupakan salah satu dari 10 anggota syuro yang ditunjuk oleh Maulana Inamul Hasan dari Rewind Pakistan. Abdul Wahab kemudian memperbarui Syuro Alami dengan menambah 11 orang anggota syuro. Namun 11 orang yang ditambah pada saat pelaksanaan ijma' di Rewind Pakistan pada November 2015 tidak disetujui oleh Maulana Saad. Sehingga insiden fisikpun terjadi, dan mengakibatkan kelompok kontra Saad dipersekusi. Saat ini Jamaah Tabligh sendiri terbelah menjadi dua kelompok, pertama kelompok pendukung Maulana Saad yang disebut dengan kelompok Nizamuddin, dan kedua kelompok yang menentang Maulana Saad sebagai amir yaitu kelompok Syuro Alami.

Setelah terjadi bentrokan, sebagian masyaikh yang menentang Maulana Saad meninggalkan markas Nizamuddin karena suasana yang tidak kondusif. Akhirnya sejak peristiwa itu para masyaikh terbelah, ada yang pro terhadap Maulana Saad dan kontra terhadap beliau. Dalam Jamaah Tabligh orang-orang tua yang telah lama bergabung yang hanya mengabdikan hidupnya untuk berdakwah disebut dengan masyaikh. Mereka memiliki otoritas dan pengaruh yang cukup kuat karena para masyaikh ini dianggap orang alim dan berilmu disebabkan pengalaman mereka yang telah lama berjuang dalam berdakwah. Para masyaikh mempunyai peluang besar untuk menjadi ahli syuro dalam Jamaah Tabligh, sehingga tidak heran ketika terjadi pertentangan antara para masyaikh terkait status amir Maulana Saad terjadi mobilisasi masa yang cukup besar diantara dua kelompok yang pro dan kontra terhadap Maulana Saad.

Kejadian tersebut manjadi awal terbaginya markas Jamaah Tabligh menjadi dua kelompok antara yang pro terhadap Maulana Saad dan kontra terhadap Maulana Saad. Saat ini kelompok pengikut Saad bermarkas di Nizamuddin sementara yang kontra di Rewind Pakistan. Setelah terjadi konflik di India, konflik juga meluas sampai ke Indonesia. Syuro Indonesia yang semula berjumlah 13 orang, terpecah dalam dua kubu. Pertama kubu Cecep Firdaus yang bermarkas di Masjid Jami' kebon Jeruk yang merupakan kelompok Nizamuddin pendukung Maulana Saad sebagai amir, dan kedua kubu Muslihuddin Jafar, pendukung Syuro Alami penentang Maulana Saad sebagai amir yang bermarkas di Masjid Al-Mutaqien Ancol. Kubu Cecep didukung oleh pondok pesantren Al-Fattah Tamboro Keras, Magetan. Pesantren ini merupakan pesantren Jamaah Tabligh terbesar dengan santri mencapai 18.000 orang. Pengasuhnya Kyai Uzairon Thoifur salah seorang ahli syuro Jamaah Tabligh Indonesia. Sedangkan kubu Muslihuddin Jafar, pendukung Syuro Alami didukung pondok pesantren Darul Mukhlasin Payaman Magelang, dan pondok pesantren Sirajul Mukhlasin Krincing Secang Magelang, pengasuhnya Kyai Mukhlisun salah seorang ahli syuro Jamaah Tabligh (Syeirazi, 2019).

\subsection{Konflik Jamaah Tabligh di Kota Padang}

Di Kota Padang, awal mula perpecahan Jamaah Tabligh terjadi ketika Cecep yang bertugas sebagai penanggung jawab syuro untuk Indonesia datang ke Padang. Setibanya di Padang, beliau tidak langsung mengunjungi markas provinsi Jamaah Tabligh di Sumatera Barat yaitu Masjid Muhammadan. Yang terjadi justru Cecep berkunjung ke Masjid Madinatul Munawarah di daerah Berok Kota Padang yang kelak akan menjadi markas pendukung kelompok Maulana Saad atau Nizamuddin. Karena Cecep tidak langsung mengunjungi Masjid Muhammadan sebagai markas provinsi, protes muncul dengan narasi yang menyinggung sosok Maulana Saad. Sebagaimana wawancara penulis dengan "S", salah seorang anggota Syuro Alami yang mengatakan:

"bapak kenapa tidak datang ke markas Masjid Muhammadan markas Provinsi Sumatera Barat, kalau bapak ke sini berarti bapak berjalan sendiri sama seperti Maulana Saad" (wawancara dengan S, 29 Agustus 2019).

Karena ada kata-kata yang demikian, menyinggung sosok Maulana Saad, terjadi terjadi perdebatan antara kelompok yang pro dan kontra terhadap Maulana Saad di hari yang sama. Perdebatan mengakibatkan terbelahnya Jamaah Tabligh di Padang menjadi dua kelompok hingga saat ini. Pertama kelompok Nizamuddin yang bermarkas di Masjid Madinatul Munawarah berok Kota Padang, kedua kelompok Syuro Alami yang bermarkas di Masjid Muhammadan Pondok Kota Padang. 
Dari konflik yang terjadi di Padang, dapat dipahami bahwa benih-benih konflik dan perbedaan pandangan terkait konflik yang terjadi di India telah terjadi di kota Padang sebelum Cecep (penanggung jawab syuro untuk Indonesia) datang berkunjung ke Padang. Hal ini terlihat dari narasi yang dikatakan oleh beberapa Jamaah saat Cecep mengunjungi Masjid Madinatul Munawarah. Telah ada rasa ketidaksukaan dari sebagian Jamaah terhadap sosok Maulana Saad atas ditetapkannya beliau sebagai amir dunia. Konflik yang terjadi justru menjadi semakin nyata terlihat ketika Cecep datang ke Padang, yang menyebabkan sebagian besar Jamaah di Masjid Muhammadan memilih untuk keluar dan bergabung dengan jamaah yang berada di Masjid Madinatul Munawarah yang merupakan markas kelompok pro Maulana Saad.

"setelah terjadi perpecahan, markas provinsi di Masjid Muhammadan sempat tidak ada orang karena sebagian besar jamaah ikut kelompok Maulana Saad. Yang tertinggal hanya penanggung jawab Masjid, dan orang-orang tua atau orang-orang lama di Jamaah tabligh" (wawancara dengan S, 29 Agustus 2019).

Dari kutipan wawancara di atas, dapat dipahami bahwa mayoritas Jamaah Tabligh di Kota Padang setelah terjadi perpecahan banyak yang ikut kepada kelompok Nizamuddin. Namun mereka yang ikut kepada Nizamuddin atau pro terhadap Maulana Saad adalah orang-orang yang belum lama bergabung terhadap Jamaah Tabligh. Sementara mereka yang ikut kelompok Syuro Alami adalah orang-orang tua (orang-orang lama), alim ulama yang telah lama bergabung. Hal di atas dipertegas Sebagaimana wawancara penulis dengan salah seorang informan YM dari Syuro Alami:

"kebanyakan orang-orang yang ikut ke Syuro Alami ini adalah orang-orang lama, orang-orang tua, dan alim ulama sementara mereka yang ikut ke Jamaah Berok (Nizamuddin), kebanyakan orang-orang muda yang baru bergabung dalam dakwah Tabligh (wawancara dengan YM, 11 Juli 2019).

Bagi kelompok Syuro Alami di kota Padang kelompok Nizamuddin dianggap sebagai kelompok yang terlalu fanatik kepada Maulana Saad sebagaimana ungkap salah seorang informan yang mengatakan:

"orang-orang yang di Berok (Nizamuddin) ini banyak yang terpengaruh karena sosok Maulana Saad, harusnya dalam soal agama atau dakwah ini bukan soal banyaknya pengikut tapi soal kebenaran" (wawancara dengan YM, 11 Juli 2019).

Lantas hal tersebut pun mendapat respon oleh salah satu anggota dari kelompok Nizamuddin yang mengungkapkan:

"Maulana Saad itu pemimpin kami, amir kami seorang yang alim. Beliau keturunan Muhammad Ilyas pendiri Jamaah Tabligh, tentu kami Jamaah mengikutinya. Tapi orang-orang di Muhammadan (kelompok syuro alami) tidak setuju beliau menjadi amir pemimpin dunia Jamaah Tabligh. Awalnya mereka sangat menyanjung-nyanjung Maulana Saad tapi sejak kisruh masalah kepemimpinan ini pandangan mereka berubah terhadap Maulana Saad. Kami dituduh fanatik ke ulama, apa salahnya beliau keturunan Maulana Ilyas seorang alim hafiz $30 \mathrm{Juz}$, banyak hafal hadis seorang ulama besar. Beliau dituduh haus kekuasaan mengejar dunia, padahal menjadi amir itu tidak digaji, tidak mendapatkan apa-apa dunia apa yang beliau kejar" (wawancara dengan H, 18 Agustus 2019).

Maulana Saad adalah Cicit dari Maulana Ilyas pendiri Jamaah Tabligh. Artinya beliau merupakan keturunan dari orang yang sangat dihormati dalam Jamaah Tabligh, oleh sebab itu Maulana Saad mempunyai pengaruh dan otoritas yang kuat dikarenakan nasabnya sampai kepada sosok pendiri Jamaah Tabligh. Ungkap salah seorang Jamaah Syuro Alami yang mengatakan bahwa:

"Maulana Saad itu cucu dari Maulana Ilyas pendiri jamaah tabligh, masa kecil beliau diasuh oleh Bay Wahab. Semasa belajar, nama beliau selalu diagung-agungkan karena beliau keturunan dari pendiri Jamaah Tabligh. Akhirnya karena selalu diperlakukan spesial, Maulana Saad merasa seperti mempunyai otoritas mutlak dalam jamaah" (wawancara dengan S, 29 Agustus 2019).

Kondisi yang terjadi di atas sesuai dengan apa yang dikatakan oleh Weber, bahwa konflik diartikan sebagai suatu sistem otoritas atau sistem kekuasaan. Bagi Weber, kekuasaan cenderung menaruh kepercayaan kepada kekuatan, sedangkan otoritas adalah kekuasaan yang dilegitimasikan, yaitu kekuasaan yang telah mendapat pengakuan umum. Senada dengan apa yang diungkapkan oleh Weber menurut Alison dan Walace kekuasaan tidak hanya merupakan sumber konflik, melainkan juga sebagai sesuatu yang bersifat memaksa. Begitupun juga seperti yang dikatakan Karl Marx bahwa tingkat ketidakmerataan distribusi 
sumber, terutama kekuasaan, merupakan determinan konflik kepentingan objektif diantara mereka yang memiliki kekuasaan dan yang tidak memiliki kekuasaan. Proposisi ini secara langsung mengikuti asumsi Marx bahwa di dalam semua struktur sosial, distribusi kekuasaan yang tidak merata pasti akan menimbulkan konflik kepentingan antara mereka yang memiliki kekuasaan dan mereka yang tidak memiliki kekuasaan (Wirawan, 2012).

Tetapi bagi kelompok Syuro Alami, nasab tidak menjadi patokan sehingga mereka tidak mau mendukung Maulana Saad. Bagi mereka, Maulana Saad dianggap telah melenceng dari aturan-aturan dakwah yang dirintis oleh kakeknya Maulana Ilyas. Ungkap salah seorang informan anggota Syuro Alami mengatakan:

"memang benar Maulana Saad nasabnya sampai kepada Maulana Ilyas, namun sanad (amal) beliau tidak sampai kepada kakeknya karena terputus tidak pernah bertemu, jadi apa yang dibuat oleh beliau banyak yang ditambah-tambah seperti buku Muntakhab Hadist. dulunya buku itu tidak ada, lalu dibuat oleh Maulana Saad sendiri" (wawancara dengan YM, 11 Juli 2019).

Jamaah Tabligh mempunyai beberapa kitab pedoman dalam berdakwah, diantaranya Fadhilah Amal yang dikarang oleh Maulana Muhammad Zakariyya Al-Kandahlawi, dan Hayatus Sahabah yang merupakan kisah-kisah para sahabat. Namun setelah Maulana Saad menulis kitab Muntakhab Hadist, kitab ini dijadikan pegangan pada saat pelaksanaan khuruj oleh kelompok pendukung Maulana Saad. Bagi kelompok Syuro Alami, buku Muntakhab Hadist dianggap banyak hadis dhoif. Namun bagi kelompok Nizamuddin, hal tersebut tidak masalah karena hadis dhoif juga bagian dari hadis nabi. Bagi kelompok Nizamuddin hadishadis dalam kitab Muntakhab hadis hanya untuk dibaca bukan untuk diamalkan, hanya sekedar untuk menambah wawasan. Saat ini presentase pengikut dari kedua kelompok di kota Padang berkisar sekitar 70\% pengikut Maulana Saad (Nizamuddin), dan 30\% kelompok Syuro Alami. Artinya, di Kota Padang jamaah Nizamuddin lebih besar dari pada jamaah Syuro Alami.

\section{Perbedaan antara Syuro Alami dan Nizamuddin}

Jamaah Tabligh di Kota Padang dalam masih tetap menjalankan kerja dakwah walaupun telah terpecah menjadi dua markas. Malam markas dan musyawarah tetap dilaksanakan sebagaimana biasanya, baik oleh kelompok Nizamuddin maupun Syuro Alami. Kegiatan tetap mereka laksanakan setiap senin dan kamis malam, tidak ada yang berubah pasca konflik terjadi. Di samping, itu pelaksanaan khuruj masih tetap berjalan normal dan pengiriman jamaah dari markas untuk melaksanakan dakwah ke daerah-daerah tetap berjalan seperti biasa. Namun ada beberapa perbedaan antara Syuro Alami dan Nizamuddin dalam menjalankan kerja dakwah baik dari pelaksanaan khuruj dan beberapa pandangan mereka seputar pemahaman keagamaan.

Perbedaan pandangan ini dapat dikatakan menjadi dasar terbentuknya konflik selain dari perebutan kursi pemimpin. Perbedaan pandangan ini terjadi ketika adanya beberapa fatwa dari Maulana Saad yang dianggap kontroversial bagi kelompok Syuro Alami. Karena bagi mereka, Maulana Saad dianggap telah melenceng dari aturan-aturan dakwah yang telah dirintis oleh Maulana Ilyas. Di samping itu, bagi Syuro Alami fatwa Maulana Saad juga dianggap berlawanan dari mayoritas pendapat jumhur ulama di Jamaah Tabligh. Hal ini menjadi cikal bakal ketidaksukaan para masyaikh terhadap Maulana Saad sehingga ketika Maulana Saad menjadi amir, terjadi polarisasi yang keras antara pendukung Maulana Saad dan yang kontra terhadap Maulana Saad. Perbedaan-perbedaan mendasar antara Nizamuddin dan juga Syuro Alami yang menimbulkan perpecahan dalam tubuh Jamaah Tabligh akan dijelaskan secara lebih rinci melalui sub bab ini.

\subsection{Ikhtilaf Penggunaan Telepon Genggam}

Maulana Saad mengeluarkan beberapa persepsi yang kontroversial berupa penggunaan Telepon Genggam (HP) berbasis android. Menurut beliau, orang yang ketika shalat membawa HP di dalam kantingnya, shalatnya tidak sah. Selai itu, membaca Al-Quran melalui HP android tidak mendapat pahala. Terkait pendapatnya ini, Maulana Saad mengungkapkan "Kamera berponsel di saku orang shalat tidak sah, dapatkan fatwa sebanyak yang kamu mau dari ulama manapun, mendengarkan dan membanca Al-Quran dari HP yang berkamera adalah aib bagi Al Quran, tidak ada pahala padanya. Berdosalah orang yang melakukannya, tidak ada pahala yang didapat. Karena dengan demikian Allah akan mencabut seseorang dengan kemampuan mengamalkan Al-Quran. Ulama yang berfatwa membolehkan dalam hal ini, menurut saya mereka adalah ulama su' (buruk). Hati dan pikiran mereka telah 
terpengaruh oleh orang Kristen dan Yahudi. Mereka adalah ulama yang sangat bodoh. Menurut saya, ulama yang berfatwa membolehkan (HP berkamera), hatinya tidak memiliki kehebatan kalamullah. Saya mengatakan ini karena satu ulama besar berkata kepada saya: "apa yang salah dengan itu" saya katakan bahwa hati ulama ini tidak memiliki kehebatan Allah, walaupun dia belajar hadis Bukhari, padahal orang non muslim-pun bisa mempelajari hadist Bukhari" (Konsel, 2017).

Bagi pengikut Maulana Saad, fatwa yang disampaikan tersebut mereka adalah hal yang wajar karena di dalam HP android banyak hal-hal yang mudharat. Misalnya, aplikasi yang ada dalam HP tersebut terkadang memunculkan iklan wanita yang tidak menutup aurat. Ditambah lagi penggunanya memiliki akun facebook yang di dalamnya tentu lebih banyak menemukan iklan-iklan yang sepatutnya tidak boleh dilihat oleh para da'i. Di saat yang sama, HP juga digunakan untuk membaca Al-Quran.Tentu hal ini adalah sesuatu yang tidak baik. Oleh karena itu membaca ayat suci Al-Quran melalui HP adalah hal yang buruk dan kurang berakhlak, sebab bagi mereka bagaimana mungkin ayat Al-Quran yang suci justru dibaca melalui benda yang di dalamnya banyak kekotoran dan mudharat.

Dalam salah satu wawancara yang penulis lakukan terhadap jamaah pro Saad, ada hal yang menarik yang disampaikan terkait larangan membaca Al-Quran melalui HP. Mereka menganalogikan orang-orang yang membaca Al-Quran melalui HP itu sama saja seperti orang yang minum kopi melalui pispot.

"membaca Al-Quran lewat HP tidak sah dan tidak mendatangkan pahala. Sebab, di dalam HP itu banyak mengandung mudharat. Ayat Al-Quran itu suci, perkataan Allah SWT diibaratkan, kalau kita membaca Al-Quran lewat HP, seolah-olah kita minum kopi di dalam pispot (tempat menampung air kencing). (wawancara dengan IB, 21 Agustus 2019).

Fatwa yang keluar dari Maulana Saad ini lantas mendapat respon dari jumhur ulama di India dan juga lembaga-lembaga keagamaan karena dianggap bertentangan dari pendapat mayoritas jumhur ulama dan juga para masyaikh Jamaah Tabligh. Bagi mereka, yang tergabung dalam kelompok Syuro Alami fatwa ini dianggap sikap ghuluww (terlalu berlebihlebihan) dalam tabligh. Sebagaimana ungkap salah seorang anggota Syuro Alami dalam salah satu wawancara:

"orang-orang Berok itu banyak yang sudah melenceng dari kesepakatan jumhur ulama, dakwahnya itu keras tidak jelas" (wawancara dengan UT, 18 Agustus 2019).

Oleh karena itu, sebagian dari para masyaikh dalam kelompok Syuro Alami ini tidak menyetujui fatwa yang dikeluarkan oleh Maulana Saad. Artinya adalah kelompok syuro alami tidak mempermasalahkan status seseorang yang membaca Al-Quran melalui HP, apakah tidak mendapatkan pahala dan berdosa atau tidak. Yang jelas kelompok syuro alami memperbolehkan seseorang yang membaca Al-Quran melalui HP.

\section{Ikhtilaf Metode Khuruj}

Sudah menjadi rahasia umum bahwa yang membedakan Jamaah Tabligh dengan organisasi keagamaan dan aliran keagamaan lain yang ada di Indonesia adalah metode dakwah yang mereka lakukan. Metode dakwah ini terbilang unik dibandingkan dengan metode dakwah organisasi keagamaan lain. Jemaah Tabligh memiliki metode dakwah yang mereka sebut dengan istilah khuruj. Khuruj berarti keluar berdakwah di jalan Allah dengan cara meninggalkan keluarga, anak, istri, pekerjaan, menuju ke segala penjuru dunia, menemui umat Islam lainnya dan mengajak mereka beramar ma'ruf nahi munkar sesuai tuntunan AlQuran dan Sunnah (Kamaruddin, 2010). Basanya dalam proses pelaksanaan khuruj, ada kegiatan berkeliling-keliling atau jaulah ke rumah-rumah warga dan kedai-kedai serta ke tempat-tempat dimanapun warga berkumpul. Di tempat-tempat tersebut mereka akan berdakwah, berbicara tentang iman, amal dan adab-adab yang sesuai tuntunan Rasulullah SAW serta mengajak masyarakat untuk selalu meramaikan Masjid (Kamaruddin, 2010). Namun setelah terjadi konflik, ada perbedaan antara Syuro Alami dan Nizamuddin seputar teknis pelaksanaan khuruj.

Menurut kelompok Syuro Alami, dakwah bisa dilakukan dimana saja baik itu di rumah di kedai-kedai dan di tempat-tempat manapun, tidak hanya di Masjid. Namun bagi kelompok Nizamuddin, dakwah hanya bisa dilaksanakan di Masjid. Teknisnya, pada saat pelaksanaan khuruj mereka tetap mengunjungi rumah-rumah warga, namun pada saat berbincangbincang dengan warga mereka terlebih dahulu mengajak warga untuk datang ke Masjid baru setelah itu di dalam Masjid didakwahkan tentang iman, amal dan adab yang sesuai tuntunan rasul. Maulana Saad sendiri pernah mengeluarkan fatwa bahwa beliau menolak dakwah di 
tempat umum, dan mengkhususkan dakwah hanya di dalam Masjid. Beliau menegaskan bahwa dakwah di luar Masjid adalah menyalahi sunnah. Salah satu informan yang merupakan anggota Syuro Alami juga membenarkan hal tersebut dengan mengatakan bahwa

"Dakwah di dalam syuro Alami itu lebih mudah datang ke rumah-rumah, ke kadai-kedai dan memberi nasehat kebenaran, tapi dari pihak Maulana Saad mengajak orang datang ke Masjid setelah itu baru didakwahkan, cara yang begini lebih berat, dakwahnya beresiko tinggi" (wawancara dengan YM, 11 Juli 2019).

Selain perbedaan prinsip berdakwah, perbedaan juga terlihat pada kitab pegangan yang dibawa pada saat pelaksanaan khuruj. Jamaah Tabligh, sebelum terpecah memiliki kitab yang wajib dibawa saat pelaksanaan khuruj, yaitu kitab Fadhilah Amal. Selama khuruj jamaah akan membaca kitab Fadhilah Amal secara bergantian dan yang lainnya mendengarkan, tujuannya adalah sebagai motivasi bagi karkun (juru dakwah). Hal ini dilakukan karena di dalamnya berisi keutamaan shalat, keutamaan dakwah, keutamaan zikir dan kisah-kisah para sahabat.

Namun Semenjak Maulana Saad menulis dan membukukan kitab Muntakhab Hadis, kitab ini wajib dibawa saat pelaksanaan khuruj oleh pendukung Maulana Saad, yang pada akhirnya merubah aturan-aturan yang dilaksanakan saat khuruj karena biasanya kitab yang dibawa hanya kitab Fadhilah Amal. Sebagaimana ungkap salah seorang informan yang merupakan anggota Syuro Alami:

"Maulana Saad telah membuat kitab Muntakhab Hadis yang di dalamnya hanya berisi hadis saja tidak ada penjelasan dari hadis itu, sehingga kitab ini banyak ditentang oleh para masyaikh" (wawancara dengan YM, 11 Juli 2019).

Namun Kelompok Nizamuddin membantah hal tersebut dan menegaskan bahwa hadishadis dalam kitab Muntakhab Hadist sebenarnya dihimpun oleh Maulana Yusuf kemudian ditulis kembali secara sistematis oleh Maulana Saad, kerena Maulana Yusuf tidak sempat menerbitkan kitab tersebut. Dalam sejarahnya, setelah Maulana Yusuf meninggal kitab ini disimpan oleh Maulana Inamul Hasan, kemudian setelah Mualana Inamul Hasan meninggal kitab ini diberikan kepada cucu Maulana Yusuf, yaitu Maulana Saad. Karena kitab tersebut disimpan oleh Maulana Saad akhirnya beliau menelaah kitabnya dan menyusun kembali agar lebih sistematis. Sebagaimana ungkap salah seorang informan yang merupakan anggota kelompok Nizamuddin:

"kitab Muntakhab Hadis itu sebenarnya hadis-hadis di dalamnya dikumpulkan oleh Maulana Yusuf, kemudian ditulis ulang kembali oleh Maulana Saad" (wawancara dengan H, 18 Agustus 2019)

Pernyataan ini menjadi sebuah bantahan dari Nizamuddin kepada Syuro Alami karena selama ini mereka menuduh kitab ini adalah buatan dari Maulana Saad sendiri padahal sebenarnya tidak. Kejadian ini tentu menjadi kontroversial, sebab bagi para masyaikh dari syuro alami kitab ini dianggap banyak hadis dhaif di dalamnya serta tidak ada penjelasan dari hadis-hadis tersebut. Maka dari itu tentu kelompok syuro alami akan menolak kitab ini dibawa saat pelaksanaan khuruj.

\section{Diskusi}

Galtung merumuskan konflik dalam bentuk segitiga yang disebut ABC Triangle. ABC Triangle dalam segitiga konflik Galtung merupakan urutan terbentuknya konflik, yang terdiri atas Attitudes (A), Behavior (B) dan Contradiction (Galtung, 2003). Menurut Galtung Attitudes mencakup asumsi, kognisi dan emosi yang dimiliki satu pihak terhadap pihak lain. Attitudes berarti adanya penolakan terhadap superioritas pihak lain. Jika dikaitkan dengan konflik Jamaah Tabligh penolakan terhadap superioritas terletak pada kelompok Syuro Alami yang menolak superioritas kelompok Maulana Saad dan para pendukungnya. Penolakan ini terjadi karena mereka mendeklarasikan Maulana Saad sebagai amir. Sikap ini tentunya akan melahirkan emosi yang negatif dari satu pihak terhadap pihak lain. Misalnya, mulai munculnya rasa ketidaksukaan terhadap Maulana Saad dan para pendukungnya. Begitupun sebaliknya para pendukung Maulana Saad mulai memunculkan sikap atau kesan yang negatif terhadap kelompok yang tidak suka terhadap Maulana Saad.

Komponen yang kedua dalam segitiga konflik adalah Behavior yang mencakup mental, ekspresi verbal atau fisik yang timbul dalam konflik. Tindakan kekerasan, sikap penghinaan dan sikap tidak hormat merupakan bentuk-bentuk Behavior dalam konflik. Behavior yang timbul dalam kasus konflik Jamaah Tabligh di Kota Padang hanya sebatas pada ekspresi 
verbal, tidak sampai pada kekerasan fisik. Artinya konflik yang muncul hanya merupakan perdebatan antar kedua kelompok. Perdebatan yang muncul diantara kedua kelompok tidak hanya sekedar perdebatan biasa, namun tidak jarang juga sering terjadi ekspresi verbal berupa penghinaan dan sikap tidak hormat diantara para Jamaah. Misalnya saja sebuah statement dari kelompok pro Maulana Saad bahwa kelompok Syuro Alami di Kota Padang merupakan pengikut Syiah. Kemudian kelompok Syuro Alami itu ibarat kelompok yang buang kotoran di atas belanga mereka sendiri sebab Jamaah ini dulunya satu kelompok. Demikian pula kelompok syuro alami yang juga melemparkan ststement yang berkonotasi negatif terhadap kelompok Nizamuddin seperti mereka mengatakan pendukung Maulana Saad merupakan kelompok Saadiyah, sebab mereka hanya taklid buta terhadap Maulana Saad dan tidak peduli apakah Maulana Saad itu salah atau benar.

Perlu diapresiasi bahwa Behavior yang muncul dalam konflik Jamaah Tabligh di kota Padang tidak sampai pada serangan atau ekspresi fisik. Konflik yang terjadi hanya terbatas pada konflik verbal dan puncaknya terjadi saat pendukung Maulana Saad keluar secara besar-besaran dari markas provinsi, dan pindah ke markas baru yang hanya diperuntukkan bagi pendukung Maulana Saad. Bagi kelompok Nizamuddin maupun Syuro Alami, menurut mereka saat ini Jamaah Tabligh sudah tidak bisa disatukan sebab adanya perbedaanperbedaan mendasar diantara kedua kelompok yang menyebabkan mereka harus terpisah.

Selanjutnya komponen yang ketiga adalah Contradiction, yaitu perbedaan tujuan antara pihak yang bertikai. Perbedaan antara kedua kelompok Jamaah Tabligh ini bisa dilihat pada sistem musyawarah. Bagi kelompok Nizamuddin, sistem musyawarah hanya diputuskan oleh amir tunggal yang ditunjuk sebagai faisalah atau pemutus musyawarah. Status Jamaah yang ditunjuk sebagai faisalah akan seterusnya berlaku, artinya adalah status faisalah tidak hanya berlaku dalam satu kali musyawarah saja tetapi di setiap jalannya musyawarah. Maka jamaah yang ditunjuk sebagai faisalah secara otomatis akan menjadi amir dakwah jamaah. Sedangkan Syuro Alami menentang sistem yang seperti ini, bagi syuro alami faisalah harus ditunjuk secara berganti-gantian dalam setiap musyawarah dari beberapa orang yang ditunjuk sebagai syuro. Dalam kelompok syuro alami tidak ada amir yang hanya ada sistem syuro, jadi orang-orang yang masuk ke dalam keanggotaan syuro secara bergantian akan memimpin jalannya musyawarah. Maka dari itu status mereka yang menjadi faisalah hanya berlaku di setiap satu kali musyawarah, tidak di setiap musyawarah, karena di musyawarah selanjutnya akan ditunjuk kembali faisalah dari anggota syuro.

Contradiction yang selanjutnya timbul dari prinsip keagamaan, yaitu perbedaan dalam masalah membaca Al-Quran melalui HP dan perbedaan seputar metode khuruj. Unsur-unsur dalam segitiga konflik ini yang terdiri dari Attitudes, Behavior, dan Contradiction menurut Galtung dapat berfungsi untuk mengidentifikasi penyebab atau faktor timbulnya konflik. Sebagaimana yang telah dijelaskan di atas, bahwa ketiga komponen tersebut muncul dalam konflik Jamaah Tabligh. Demikianlah menurut Galtung dari teori segitiga konflik yang dicetuskannya, bahwa komponen-komponen tersebut harus muncul dalam sebuah konflik total.

\section{Kesimpulan}

Berdasarkan hasil penelitian sebagaimana telah diuraikan di atas, dapat ditarik sebuah kesimpulan bahwa awal mula pecahnya Jamaah Tabligh berasal dari markas pusat di Nizamuddin India. Perpecahan tersebut disebabkan karena perbedaan pandangan dalam memutuskan amir. Konflik mulai terjadi ketika Maulana Saad diangkat sebagai amir, kelompok yang kontra melakukan perlawanan karena Maulana Saad dianggap memutuskan secara sepihak. Di saat itulah Jamaah Tabligh terbelah menjadi dua kelompok, yaitu kelompok Nizamuddin (pihak pendukung Maulana Saad) dan kelompok Syuro Alami (pihak penentang Maulana Saad). Konflik dari pusat menjalar sampai ke Indonesia dan kota Padang. Setelah konflik, Jamaah Tabligh di Padang terbagi dalam dua kelompok, yaitu Syuro Alami yang bermarkas di Masjid Muhammadan Pondok Kota Padang, serta kelompok Nizamuddin yang bermarkas di Masjid Madinatul Munawarah Berok Kota Padang.

Pada dasarnya, konflik yang terjadi pada Jamaah Tabligh sendiri tidak jauh berbeda dengan konflik-konflik di tempat lain, baik itu konflik internal organisasi maupun konflik satu organisasi dengan organisasi yang lain. Biasanya konflik diawali dengan kontradiksi setelah itu muncul perubahan attitude dan ada aksi (behavior). Sebagaimana Galtung mengungkapkan dalam teorinya bahwa ketiga komponen ini harus muncul dalam konflik total. Adapun attitude yang ditemukan dalam konflik Jamaah Tabligh adalah adanya 
penolakan salah satu kelompok terhadap kelompok lain yang memiliki superioritas. Penolakan ini membentuk emosi yang terkesan negatif diantara kedua kelompok, yakni Nizamuddin dan Syuro Alami. Kemudian behavior yang muncul dalam konflik Jamaah Tabligh hanya sebatas pada ekspresi verbal, tidak sampai pada ekspresi fisik. Artinya, konflik hanya terbatas pada adu mulut semata, tidak mengarah pada perusakan atau penyerangan secara fisik. Dan yang terakhir adalah contradiction. Kontradiksi dalam Jamaah Tabligh terletak pada perbedaan seputar sistem musyawarah dan kepemimpinan. Bagi kelompok syuro alami, mereka lebih setuju sistem kologial yang diterapkan dalam Jamaah Tabligh, sementara bagi kelompok Nizamuddin mereka lebih setuju sistem keamiran (pemimpin tunggal) yang diterapkan dalam Jamaah Tabligh. Selain itu, contradiction yang muncul juga menyentuh ranah pemikiran keagamaan seperti status seseorang membaca Al-Quran melalui HP dan perbedaan dalam metode berdakwah. Kelompok Nizamuddin meyakini bahwa seseorang yang membaca Al-Quran melalui HP bacaanya tidak akan mendapat pahala dan tidak sah, dan dakwah menurut mereka hanya boleh dilaksanakan di Masjid. Sementara kelompok Syuro Alami menentang hal itu, bagi mereka dakwah boleh dilakukan dimana saja dan membaca Al-Quran melalui HP hukumnya boleh dan bacaannya tetap sah.

\section{Conflicts of Interest}

Penulis menyatakan tidak memiliki conflict of interest antara penulis dengan subjek penelitian dalam penulisan artikel ini.

\section{Daftar Pustaka}

Galtung, J. (2003). Studi Perdamian: Perdamian dan Konflik Pembangunan dan Peradaban, terj Asnawi dan Safruddin,. Surabaya: Surabaya: Eureka.

Gati, G. N. P. B. (2014). Dinamika dan Faktor Pendorong Keberlanjutan Konflik Antara Masyarakat Tuareg dengan Pemerintahan Mali (1962-2012). Jurnal Analisis Hubungan Internasional, 3(3).

Junaedi, D. (2013). Memahami Teks, Melahirkan Konteks: Menelisik Interpretasi Ideologis Jamaah Tabligh. Journal of Qur'an and Hadith Studies, 2(1), 1-17. https://doi.org/10.1548/quhas.v2i1.1274

Kamaruddin, S. A. (2010). Jamaah Tabligh. Jakarta: Gaung Persada Press.

Konsel, M. (2017). Seberkas cahaya dari nizamuddin.

Miall, H. (2002). Resolusi Damai Konflik Kontemporer Menyelesaikan, Mencegah, Mengelola, dan Mengubah Konflik bersumber Politik, Sosial, Agama dan Ras, terj Tri Budhi Sastrio,. Jakarta: Jakarta: RajaGrafindo Persada.

Miles, M. B., \& Huberman, A. M. (1992). Analisis Data Kualitatif: Buku Sumber Tentang Metode-Metode Baru. Jakarta.: UI Press.

Musyawarah ahli syuro dan para jumidar. (2018). Mudzakarah Enam Sifat Sahabat. Jakarta: Assalam.

Saepuloh, U. (2014). Model Komunikasi Dakwah Jamaah Tabligh. Ilmu Dakwah: Academic Journal for Homiletic Studies, 4(14), 657-688.

Sugiyono. (2019). Metode Penelitian Kualitatif Kuantitatif. Bandung: Alfabeta.

Syeirazi, M. K. (2019). Jamaah Tabligh Salafi Van India.

Tholhah. (2015). Perkembangan jamaah tabligh di wilayah yogyakarta. Prosiding Interdisciplinary Postgraduate Student Conference 1st Program Pascasarjana Universitas Muhammadiyah Yogyakarta (PPs UMY), 12-17.

Umdatul Hasanah. (2014). Keberadaan Kelompok Jamaah Tabligh dan Reaksi Masyarakat (Perspektif Teori Penyebaran Informasi dan Pengaruh). Indo-Islamika, 4(1), 21-40.

Wirawan, I. B. (2012). Teori-Teori Sosial dalam tiga paradigma fakta sosial, definisi sosial dan perilaku sosial,. Jakarta: Jakarta: Kencana Prenada Media Group.

Witrianto. (2015). Perkembangan Jamaah Tabligh di Kota Padang", Ilmu sejarah Universitas Andalas Padang. Ilmu Sejarah Universitas Andalas Padang, 10-14.

Yusuf, M. (2015). Prinsip Ikram Al-Muslim Gerakan Dakwah Jamaah Tabligh dalam Membangun Masyarakat Religius di Temboro Magetan. Islamica: Jurnal Studi Keislaman, 10(2), 300-301. https://doi.org/10.15642/islamica.2016.10.2.299-324 